ISSN: 0213-3563

http://dx.doi.org/10.14201/azafea201921209219

\title{
LA TEORÍA ECOLÓGICA DE JOHN DRYZEK: 30 AÑOS DE PENSAMIENTO POLÍTICO AMBIENTAL
}

\author{
The ecological theory of John Dryzek: 30 years of environmental \\ political thought
}

\section{Carmen Velayos-Castelo y Javier Romero Muñoz}

John Dryzek visitó España en el mes de noviembre de 2018. Salamanca y Madrid fueron los destinos acordados por el profesor anglo-australiano, con motivo de formalizar la dirección de una tesis doctoral sobre teoría política ambiental, además de por una serie de conferencias sobre la política en el Antropoceno. Británico de nacimiento (en 1953), la formación inicial de John Dryzek en ciencia política y economía estuvo acompañada por su activismo pacifista y ecológico; un activismo que nunca ha abandonado junto a su defensa del vegetarianismo (vegetariano desde hace casi cuarenta años) y su ferviente práctica de alpinista. El doctorado lo obtuvo en la Universidad de Maryland, Washington DC, donde empezó a familiarizarse con la teoría ecológica, la teoría de Georgescu Roegen, el análisis institucional y la filosofía de Jürgen Habermas, entre otros.

La Universidad de Oregon, la Universidad de Melbourne, la Universidad Nacional Australiana (ANU) y, finalmente, la Universidad de Canberra, han sido los hogares académicos de John Dryzek durante más de treinta años de pensamiento ecológico. El fruto de estos años se traduce no sólo en numerosos artículos, colaboraciones, ediciones, manuales y libros, sino además en la creación del Centre for Deliberative Democracy and Global Governance en Canberra, Australia, un lugar de encuentro y reunión para todos los seres vivos (en la etnia aborigen Ngunnawal, Kanberra significa "lugar de reunión”). $\mathrm{Y}$ es que bien sabe Dryzek, según señalan sus primeras publicaciones a principios de los años ochenta, que la ecología y la sociedad van de la mano, y que la comunidad biótica debe ser extendida no solo a los animales humanos, sino también a los animales no humanos (Dryzek, 1983). 


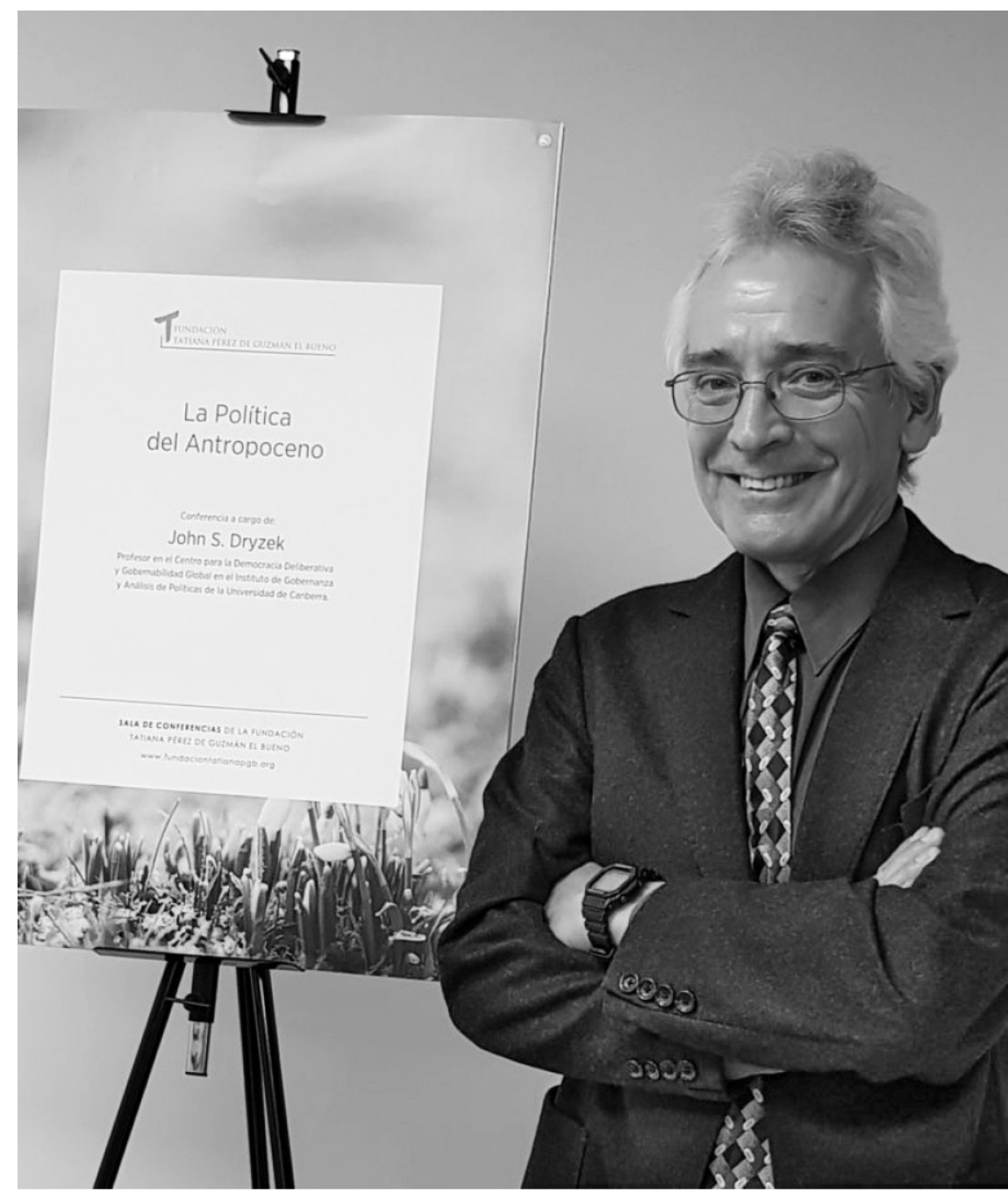

FIgura 1: John Dryzek (Fuente: Nota de prensa realizada para el blog del Colegio Oficial de Ingenieros de Montes, 29 de Noviembre de 2018. Autor: Pilar Quijada Garaballú) ${ }^{1}$.

Desde 1983 ha participado activamente, primero en EE. UU. y después en Australia, en el desarrollo filosófico, ético y político de una teoría a tres niveles: nivel filosófico, nivel ético y nivel político. Ya en Rational Ecology.

1. http://blog.ingenierosdemontes.org/2018/11/john-s-dryzek-el-antropocenonos-devuelve-a-un-mundo-tan-inestable-como-el-anterior-a-nuestra-especie/ 

POLÍTICO AMBIENTAL

Environment and Political Economy (1987), hay indicios de estos tres niveles cuando estructura teóricamente la idea de racionalidad ecológica (capacidad de los ecosistemas de proporcionar de forma consciente y efectiva los bienes de soporte vital a la vida humana) (Dryzek, 1987: 36). Aplicando este tipo de racionalidad, Dryzek se da cuenta de que filosóficamente puede desarrollarse en términos ecológicos si se adopta una perspectiva naturalista (la racionalidad de los ecosistemas), en términos éticos si se adopta una perspectiva universalista (ecoética comunicativa), y en términos políticos si se adopta una perspectiva interdisciplinaria (criterios de elección social en democracia deliberativa), según recogen varios de sus artículos y obras (Dryzek, 1987; 1990; 1995; 2000: 140).

Para el caso de la teoría filosófica, Dryzek ha logrado en estos años sintetizar una serie de extensiones a la clásica noción de acción comunicativa de Jürgen Habermas (Dryzek, 1990; 1995, 2000: 148-150). Para el autor, los presupuestos teóricos de Habermas estarían anclados en la tradición de la comunicación lingüística, que tendrían su aplicación práctica únicamente sobre comunidades de diálogo e intercambio comunicativo entre seres humanos. La crítica de Dryzek a Habermas se centra en mostrar que la comunicación es, sobre todo, biocomunicación (naturalismo), y que la acción comunicativa puede llegar a extenderse hacia entidades (entities) que pueden llegar a actuar como agentes (agents), aunque carezcan de la autoconciencia propia que connota la subjetividad (subjectivity). La agencia no sería lo mismo, para el autor, que la subjetividad, y solo la primera necesitaría buscarse en la naturaleza mediante señales y significados que, en este caso, no serían lingüísticos (comunicación no lingüística). Para Dryzek, así como para su amiga y seguidora Val Plumwood, la naturaleza no es pasiva, ni inerte, ni plástica, sino que estaría viva e impregnada de significados mediante señales y signos no verbales, ya sean signos bióticos (rostro, vista, olfato, emociones, feromonas, comunicación vocal, etc.) o signos abióticos (desertificación, decoloración, sequía, deshielo, etc.) (Dryzek, 1990; 1995; 2000. Val Plumwood, 2001).

Escuchar las señales y los signos que proceden de la naturaleza gracias a este desarrollo teórico-filosófico (entre la semiótica, la tradición universalista kantiana, la teoría del reconocimiento y la biología moderna y teoría ecológica) conduciría hacia una ecoética comunicativa (Dryzek, 1990). Según D. Torgerson, Dryzek habría restaurado en su obra un link comunicativo entre los seres humanos y la naturaleza (más allá del antropocentrismo y el biocentrismo), gracias a que recurre a otros géneros de comunicación capaces de evocar esas sutiles comprensiones que, por lo general, resultan elusivas a 
la comprensión contundente, aunque a menudo torpe, de la argumentación directa y literal (Torgerson, 1999: 139-140). Así lo ve también R. Gunderson, cuando afirma que una de las respuestas teóricas directas de Dryzek a Habermas ha sido extender la comunicación a otros caminos que no solo serían lingüísticos (Gunderson, 2014).

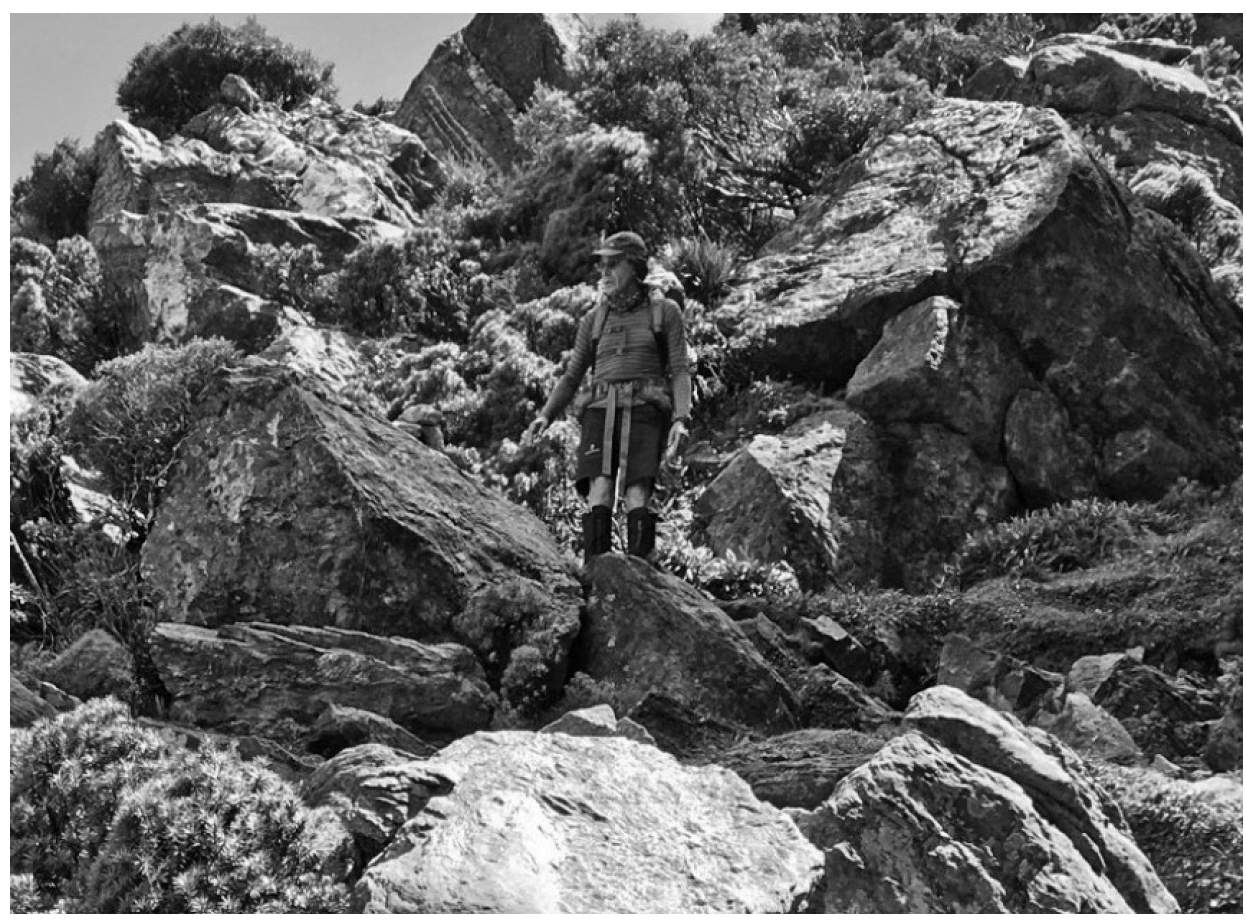

FIgURA 2: John Dryzek en una montaña de Australia (Fuente: End of Year Report 2018, 19 de Diciembre de 2018. Autor: Centre for Deliberative Democracy and Global Governance)2.

Aquí Dryzek, en la tradición de la ética ecológica, busca una ética mínima de principios universales orientados hacia la justicia comunicativa $a^{3}$. Fruto de este desarrollo teórico son una serie de principios ecológicos, sobre el respeto por los medios de percepción proporcionados por la naturaleza (principio ecológico 1), así como el respeto por cualquier organismo que sostenga el medio

2. https://www.governanceinstitute.edu.au/magma/media/upload/ckeditor/files/ DelibDem2018.pdf.

3. Sobre los distintos desarrollos en ética ecológica, remitimos a los libros de N. Sosa y C. Velayos (Sosa, 1994; Velayos-Castelo, 1996). 

POLÍTICO AMBIENTAL

(principio ecológico 2). Este reconocimiento de la agencia en la naturaleza significa para Dryzek que "debemos escuchar las señales que emanan del mundo natural con el tipo de respeto que otorgamos a la comunicación que emana de los sujetos humanos, y que requiere de una interpretación igualmente cuidadosa" (Dryzek, 2000: 149).

Gracias a estos dos desarrollos teóricos (filosófico y ético), Dryzek finalmente ha desarrollado una teoría política ecológica en términos de democracia ecológica (ecological democracy). La estructuración de la racionalidad ecológica de un sistema social conduce finalmente a presentar una serie de criterios de elección social para las instituciones y otros tipos de racionalidad (como la económica, la social, la jurídica o legal y la política). Esto significa, en este tipo de democracia (ecológica), una ecologización de la economía, una ecologización de la sociedad, una ecologización del derecho y una ecologización de la política, donde la racionalidad ecológica se prioriza para una adecuada relación entre el ser humano y el medio ambiente.

Esta racionalidad ecológica de un sistema social conduciría mediante unos criterios de elección social, gracias a las características ecológicas de los ecosistemas (regidas por la teoría termodinámica), a un estudio de las circunstancias y la naturaleza de los problemas ecológicos, a una estructuración teórica de una teoría moral que priorice el soporte vital, y finalmente hacia un modelo político estructurado en términos de democracia deliberativa verde o democracia ecológica (Dryzek, 2000: 140-161). La democracia ecológica de Dryzek situaría la comunicación en la base de su estructura política según señala en The Politics of the Earth (Dryzek, 2013: 233). Para el autor, no solo la agregación de preferencias (como en la democracia liberal), así como la comunicación lingüistica sobre intereses humanos (como en la democracia deliberativa clásica), serían temas prioritarios en teoría de la democracia, sino que la teoría también puede llegar a desarrollarse, para una mejor integración de la comunidad política y la comunidad ecológica, mediante distintos desarrollos filosóficos y éticos que Dryzek habría desarrollado durante estos años a la clásica democracia deliberativa de Habermas.

La posibilidad que ofrecería la deliberación en ecología política, frente a otros modelos políticos, en palabras del teórico A. Dobson permitiría hacer también una referencia en democracia a la capacidad de escuchar (listen), así como de hablar (speak) (Dobson, 2010). En The Politics of the Earth, Dryzek estructura los diferentes discursos sobre los modelos y los proyectos desarrollados hasta la actualidad en la trayectoria histórica del ecologismo desde mediados del siglo XX en adelante (Dryzek, 2013). Para el autor, los 
discursos medioambientales podrían estructurarse finalmente en un modelo democrático que permitiría establecer un lugar donde ideas, posiciones, opiniones, argumentos, críticas, modelos y teorías marchan juntos, en una suma de comunicación sobre un mismo tema: el medio ambiente ${ }^{4}$. La democracia ecológica de Dryzek sería inclusiva, y permitiría que una idea o desarrollo sea debatido dialógicamente por diferentes actores, con la finalidad de llegar a un consenso mediante los mecanismos de la argumentación clásicos de $\mathrm{Ha}$ bermas. Así entonces, la democracia en estos términos ofrecería un tablero deliberativo sobre temas ecológicos prioritarios para el soporte vital de la naturaleza humana y la naturaleza no humana. Entre varios temas destacan el cambio climático antropogénico, el agotamiento de recursos naturales, la pérdida de biodiversidad y la extinción de especies, entre otros. Temas analizados por Dryzek durante estas décadas.

Según estudios analíticos, Dryzek se considera hoy uno de los 20 teóricos políticos más importantes cuyo trabajo actual tendrá una influencia expo-

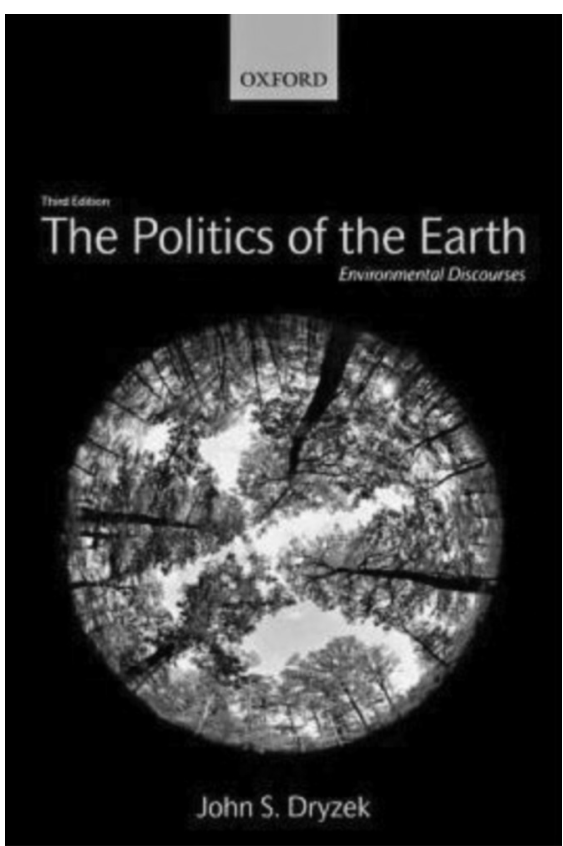

Figura 3: The Politics of the Earth, 3 ed. (Fuente: Oxford University Press). nencial en los próximos años (Moore, 2010). Ha desarrollado durante más de 30 años una teoría política ecológica con una base filosófica y ética sólida más allá del cientificismo, la metafísica y los antropocentrismos y biocentrismos que acompañan a muchos autores de la ética ambiental. Su apuesta es presentar una ética y política humana que sitúe al Homo sapiens en relación filogenética con los demás seres vivos y los ecosistemas, para resaltar la interdependencia y la ecodependencia entre los seres humanos, los demás animales y la naturaleza.

4. Dryzek analiza minuciosamente todos los discursos (metadiscurso): gestión ambiental (racionalismo administrativo, pragmatismo democrático, racionalismo económico), límites y supervivencia (survivalism, límites planetarios), sostenibilidad (desarrollo sostenible, modernización ecológica) y radicalismo verde (conciencia verde y política verde). Estos análisis ocupan nueve de los once capítulos de The Politics of the Earth. 
Ante esta realidad, la teoría de John Dryzek y su modelo de democracia ecológica posiblemente estarían mejor posicionadas que otras teorías políticas para hacer frente a las inestabilidades eco-sociales (por ejemplo, sintetizadas en el término Antropoceno). Esto es quizás suficientemente válido para entender que la cuestión es aún más prioritaria hoy cuando se analiza que algunos sistemas políticos, independientemente de su ideología o de su intento de adaptación ecológica (como la democracia liberal), estarían más capacitados que otros para llevar a cabo un compromiso más fuerte con los sistemas naturales y, por lo tanto, poder hacer frente de manera más efectiva a los problemas complejos eco-sociales.

Visto así, cabe preguntarse hasta qué punto estas contribuciones dryzeknianas durante más de 30 años de trabajo teórico y empírico no van solamente dirigidas hacia una determinada corriente de filosofía política (deliberativa-discursiva-habermasiana), sino también hacia una ecología universal en términos filosóficos, éticos y políticos, que incluya a todos los discursos enfocados al medio ambiente para un debate común sobre nuestro futuro en relación con las generaciones futuras y los animales no humanos.

\section{REFERENCIAS}

Moore, J. (2010). Political theory today: results of a national survey. Political Science E Politics, 43(2), 265-272.

Dobson, A. (2010). Democracy and Nature: Speaking and Listening, Political Studies, $58,752-768$.

DrYZEK, J. (1983). Ecological Rationality. International Journal Environmental Studies, vol. 21, 5-10.

DryzeK, J. (1987). Rational Ecology. Environment and Political Economy. New York, Basil Blackwell.

DrYZEK, J. (1990). Green Reason. Communicative Ethics for the Biosphere. Environmental Ethics, vol. 12, 195-210.

Dryzek, J. (1995). Political and Ecological Communication. Environmental Politics, vol. 4(4), 13-30.

Dryzer, J. (2000). Deliberative Democracy and Beyond. Liberals, Critics, Contestations. Oxford, Oxford University Press.

Dryzek, J. (2013). The Politics of the Earth. Environmental Discourses. Oxford, Oxford University Press.

Gunderson, J. (2014). Habermas in environmental thought: Anthropocentric Kantian or forefather of ecological democracy? Social Inquiry, vol. 84, 626-653. 
Plumwood, V. (2001). Nature as Agency and the Prospects for a Progressive Naturalism. Capitalism Nature Socialism, 12(4), 3-32.

SosA, N, 1994, Ética ecológica, Madrid, Libertarias/Prodhufi.

Torgerson, D. (1999). The Promise of Green Politics. Environmentalism and the Public Sphere. Durham NC, Duke University Press.

Velayos-Castelo, C. (1996). La dimensión moral del ambiente natural: ¿necesitamos una nueva ética? Granada, Editorial Comares. 

POLÍTICO AMBIENTAL

\section{ENTREVISTA A JOHN DRYZEK}

Your recent work focuses on the climate challenge - The Oxford Handbook of Climate Change and Society (2011), Climate-challenged society (2013), Democratizing Global Climate Governance (2014). Why is climate change so ubiquitous in current environmental debates? Is environmental politics been reduced to climate politics?

Joaquin Valdivielso, Universitat de les Illes Balears

Climate change does seem to have come to subsume a lot of environmental debates in the past 10-15 years. Of course this coincides with the rise in concern for the climate and the increasingly obvious lack of capacity of most governments and the UNFCCC to respond adequately to the issue. At the same time, climate change is just one aspect of global environmental change, and so not everything should be subordinated to it. Climate change is of course just one of the nine planetary boundaries identified by Earth scientists. My co-editor of The Oxford Handbook of Climate Change and Society Richard Norgaard actually wanted to make it The Oxford Handbook of Environmental Change and Society, but that is not what we had agreed with the publisher.

In The Politics of the Earth, you seem pessimistic about "good intentions and sensibilities" as the best way to protect ecosystems as the forests of the American West. I agree with you that social structures matter, or that "interventions in complex systems can produce counterintuitive results”. Anyway, I am unable of thinking about Anthropocene democracy without some philosophical premises [anthropological or even scientific-ontological foundations, as a new agreed (in some sense) relation of humans with nature]. Even you select some philosophical varieties of green consciousness, as Deep Ecology, Ecofeminism, Bioregionalism, but forget many others, or different interpretations of these philosophies as the last writings of Naess about the primacy of humans. Is rational ecology the way to give a place to philosophical thinking? Why do you prefer talking of green consciousness than of green philosophical thinking?

Carmen Velayos-Castelo, University of Salamanca

The Politics of the Earth is not a book about philosophy. And the material on green consciousness is just one chapter. For that chapter, I did not 
attempt to be comprehensive on different philosophical positions, but selected only those which seemed to have particular resonance in green movements. Democracy in the Anthropocene does I think need to involve different relationships to the non-human world, but that is not necessarily or even mainly a question of philosophy either. It also a question of how we organize political systems and structures more generally so they cannot so easily ignore feedback from the earth system.

Is the case of the Anthropocene a sequel in the saga of culture / science wars, and even a product of contemporary markets of truth / post-truth?

Javier GIL, University of Oviedo

The Anthropocene began as a scientific concept, or at least a concept proposed by scientists. It has however been deployed and interrogated extensively in the social sciences and humanities. While I can see the point of those who deconstruct and criticize the concept, I also get a bit impatient with them. The Anthropocene idea does I think capture and dramatize the interlinked buman-induced threats to the Earth system. It seems a bit distant from those who traffic in post-truth politics. I'm guessing Donald Trump has never even beard of the Antbropocene!

Your research line on deliberative cultures at the University of Canberra is of an extraordinary interest. I wonder if you could tell us more about both the opportunities and also the difficulties you have experienced for its development.

María G. Navarro, University de Salamanca

The basic idea of this work is that deliberation is a universal human capacity, but manifested very differently in different cultures. I wish the work were further along, we have not really done any extensive empirical studies yet. I have been distracted by other things. I don't think there are any insuperable difficulties, it is just a matter of finding time. The biggest challenge may be in identifying particular deliberative cultures; they should not be equated with national cultures. The number of deliberative cultures in the world is indeterminate.

The proposal of "ecological reflexivity" does not appear as excessively rationalist and optimistic? We would like our societies to become ecologically 
reflective, but are we on the way to it precisely when we are running out of time for the radical transformations that we know are necessary?

Jorge Riechmann, Autonoma University of Madrid

The idea of ecological reflexivity is indeed rational, but I do not think it is excessively rationalistic. That is, it does not attempt to subordinate or displace different kinds of situated knowledges. It is a critical standard or aspirational ideal, but of course we are a long way from achieving it in anything like adequate fashion. I am not especially optimistic that dominant human institutions will be able to achieve it and so prevent ecological catastrophes. But I do not see what kinds of radical transformations could possibly work better - or work without also being accompanies by ecological reflexivity.

In your speech to the Spanish audience in 2018 you referred to the "democratic Anthropocene". Would you agree with the view that the open character of the "deliberative democracy" can help democratize the "new geological epoch" in eco-social terms?

Javier Romero, University of Salamanca

I do not believe that the democratic Anthropocene should be completely open-ended, because that would mean that everything reduces to democracy, and (for example) sustainability has no ecological content. Democracy has some ecological preconditions that should not be violated. So democratization of the Anthropocene should proceed within broad ecological boundaries. A democratic Anthropocene would feature both democratic and ecological values, which may sometimes be in constructive tension. 
